\title{
LATE RESULTS OF RESECTIONS FOR TUBERCULOSIS OF THE UPPER LOBE
}

\author{
BY \\ E. HOFFMAN
}

From Poole Sanatorium and Shotley Bridge Hospital, Newcastle-upon-Tyne

(RECEIVED FOR PUBLICATION NOVEMBER 19, 1955)

Resection in upper lobe disease in pulmonary tuberculosis has now become a routine procedure, but long-term observations of the results of these operations are still few. In all 112 patients were subjected to resection between November, 1949, and June, 1954, at Poole Sanatorium, near Middlesbrough, and at Shotley Bridge Hospital, and of these 100 have been followed up from one to six years (Table 1). These results have been correlated with the pre-operative findings and post-operative progress within the first 12 months after operation.

TABLE I

\begin{tabular}{|c|c|c|c|c|c|c|}
\hline \multicolumn{7}{|c|}{ FOLLOW-UP PERIOD } \\
\hline \multirow{5}{*}{$\begin{array}{l}1-2 \text { yea } \\
2-3 \\
3-4, \\
4-5 \\
5-6,\end{array}$} & .. & .. & $\ldots$ & . & 38 & atients \\
\hline & .. & .. & . & .. & 26 & ", \\
\hline & . & .. & . & . & 16 & ", \\
\hline & .. & . & . & .. & 9 & ", \\
\hline & . & . & .. & . & 11 & ", \\
\hline & Total & .. & .. & . & 100 & , \\
\hline
\end{tabular}

During this period there were a further 12 patients who had a resection for upper lobe disease. Of these four died within the first three post-operative months and one 10 months after operation. Of the remaining seven patients, three could not be traced and a satisfactory long-term follow-up was not available in four. However, it is known that amongst these seven patients there were two early post-operative complications. One developed a bronchopleural fistula and the other had a spread of disease. Both these complications were well controlled with a thoracoplasty.

TABLE II

\begin{tabular}{|c|c|c|c|c|}
\hline \multicolumn{5}{|c|}{ EXTENT OF RESECTION } \\
\hline \multirow{4}{*}{\multicolumn{3}{|c|}{$\begin{array}{l}\text { Local " wedge" } \\
\text { Segmental resection (single or mul- } \\
\text { tiple) } \\
\text { Lobar resection } \ldots \\
\text { Lobar and segmental resection }\end{array}$}} & \multicolumn{2}{|c|}{11 cases } \\
\hline & & & 36 & \\
\hline & & & & ", \\
\hline & & & & \\
\hline & Total & .. & 100 & , \\
\hline
\end{tabular}

Table II shows the extent of the resections, and the indications for resection are set out in Table III.
The circumscribed caseous foci included two groups: (a) those which had previously shown clinical and radiological evidence of pulmonary tuberculosis, and $(b)$ those where the diagnosis was uncertain. Cases in the first group were shown to be either the end-result of a more widespread tuberculous infiltration or inspissated cavities.

TABLE III

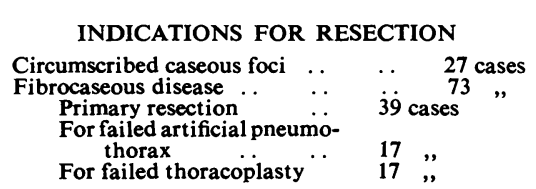

Fibrocaseous disease is the commonest form of disease for which surgery is indicated. Cavitation is usually present. It has been our experience that post-operative complications were more often found in the presence of large cavities. Four of the five early post-operative deaths occurred in cases with large single or multiple cavities. Our best results were obtained in 15 patients in whom some degree of atelectasis was present pre-operatively. In the presence of atelectasis intrathoracic adjustments have already occurred and the residual lung after resection easily fills the hemithorax. Early post-operative expansion of the residual lung has proved to be of importance in the prevention of bronchopleural fistula.

In the last two years bronchography has been a routine procedure in the assessment of cases for resection at Poole Hospital. Demonstration of bronchial disease was helpful not only in localization but also in determination of the degree of lung shrinkage. If tomography and bronchography show that a large proportion of the lung volume is diseased it has been our practice to do a preliminary one-stage thoracoplasty.

In 17 patients resection was carried out following a failed artificial pneumothorax. The pneumothorax had been maintained from two months to 
four years. The most frequent reasons for abandoning the pneumothorax were spread of disease, atelectasis, and persistent effusion. In two cases resection was performed in the presence of an empyema.

In nine patients a phrenic crush had been done six months to four years before operation. In all cases but one the diaphragm had recovered its function by the time of the resection. There w'ere no early post-operative complications in this group of patients. The phrenic crush was usually combined with a pneumoperitoneum. Altogether 12 patients had had a pneumoperitoneum for some time before operation without any appreciable therapeutic effect.

Seventeen of our patients had resections following failed thoracoplasties where there was residual cavitation and a persistently positive sputum.

In 19 patients there was radiological evidence of bilateral disease. Seven of these were operated on on both sides; four had bilateral resections and three had a thoracoplasty on one side and a resection on the other side. The results of resection in patients with bilateral disease were not good. Two of the early post-operative deaths were in this group. Of the 19 patients, only 11 showed a good result. In five patients there was an early or late reactivation or spread of disease, in two a bronchopleural fistula, and in one where a thoracoplasty had been done a chronic infection of the Semb's space developed.

All patients had an operative cover of streptomycin and P.A.S., and after its introduction isoniazid (I.N.A.H.) was also used. The majority of patients also had a pre-operative course of chemotherapy lasting one to four months.

Of the 100 cases in this series, 78 had a positive sputum pre-operatively. It is seen from Table IV

TABLE IV

FAILURE OF SPUTUM CONVERSION

\begin{tabular}{|c|c|c|c|c|}
\hline \multirow[b]{2}{*}{ Results } & \multirow{2}{*}{$\begin{array}{c}\text { No. of } \\
\text { Cases with } \\
\text { Positive } \\
\text { Sputum } \\
\text { Post- } \\
\text { operatively }\end{array}$} & \multirow[b]{2}{*}{$\begin{array}{c}\text { Conversion } \\
\text { after } \\
\text { Further } \\
\text { Treatment }\end{array}$} & \multicolumn{2}{|c|}{ Persistently Positive } \\
\hline & & & $\begin{array}{c}\text { With } \\
\text { Radiological } \\
\text { Evidence of } \\
\text { Disease }\end{array}$ & $\begin{array}{c}\text { With No } \\
\text { Radiological } \\
\text { Evidence of } \\
\text { Disease }\end{array}$ \\
\hline $\begin{array}{l}\text { Early (within } 12 \\
\text { months) } \\
\text { Late (1-3 years } \\
\text { post-opera- } \\
\text { tively) } \\
\text { 3-6 years post- } \\
\text { operatively.. }\end{array}$ & $\begin{array}{l}1 \\
2\end{array}$ & - & - & $\begin{array}{l}1 \\
1\end{array}$ \\
\hline
\end{tabular}

that in a large proportion of patients resection has resulted in permanent sputum conversion. Chemotherapy has altered the significance of the absence of tubercle bacilli in sputum examinations. Recently (1955) it was found at Poole Sanatorium that of 253 patients with radiological evidence of disease the last sputum was found to be negative on direct examination in 218 .

It is of interest that except for one case there was no radiological evidence of reactivation or spread of disease in the late follow-up. Table $\mathrm{V}$

TABLE V

PERSISTENCE, SPREAD, OR REACTIVATION OF DISEASE FOLLOWING RESECTION IN 100 CASES

\begin{tabular}{|c|c|c|c|}
\hline Activity & $\begin{array}{l}\text { No. of } \\
\text { Cases }\end{array}$ & $\begin{array}{c}\text { Controlled } \\
\text { with Further } \\
\text { Treatment }\end{array}$ & Persistent \\
\hline $\begin{array}{l}\text { Early (within } 12 \text { months) } \\
\text { Late (1-6 years post- } \\
\text { operatively) } \ldots \text {. }\end{array}$ & $\begin{array}{l}8 \\
1\end{array}$ & $\begin{array}{r}4 \\
-\end{array}$ & $\begin{array}{l}4 \\
1\end{array}$ \\
\hline
\end{tabular}

shows the numbers of cases in which the disease spread or was reactivated after resection. Disease in the residual lung was usually reactivated in patients where some disease was palpable at operation in the residual lung. We do not consider that over-distension plays a part in the aetiology of reactivation, as this followed with equal frequency in cases where resection alone or resection and thoracoplasty had been carried out.

Bronchopleural fistula is the most serious postoperative complication (Table VI). Prolonged

TABLE VI

INCIDENCE OF BRONCHOPLEURAL FISTULA FOLLOWING RESECTION

\begin{tabular}{|c|c|c|c|}
\hline Results & $\begin{array}{l}\text { No. of } \\
\text { Cases with } \\
\text { Broncho- } \\
\text { pleural } \\
\text { Fistula }\end{array}$ & $\begin{array}{c}\text { Controlled } \\
\text { by } \\
\text { Thoraco- } \\
\text { plasty }\end{array}$ & $\begin{array}{c}\text { Persistent } \\
\text { Fistula or } \\
\text { Semb's } \\
\text { Space } \\
\text { Infection }\end{array}$ \\
\hline $\begin{array}{l}\text { Early (within } 12 \text { months) } \\
\text { Late ( } 1-6 \text { years } \\
\text { operatively) } \ldots \\
\text { post- } \\
\text {. }\end{array}$ & $\begin{array}{l}8 \\
1\end{array}$ & $\begin{array}{l}5 \\
1\end{array}$ & $\begin{array}{r}3 \\
-\end{array}$ \\
\hline
\end{tabular}

pre-operative chemotherapy, and particularly the use of I.N.A.H., has more recently greatly reduced the incidence of this complication. Results in any follow-up will largely depend on the selection of cases for surgery. A series which includes a high proportion of caseous foci would be expected to have better results than one where the majority of cases have cavitated fibrocaseous disease.

We have also made a study of various factors which might have influenced the post-operative progress. The age, family history, known duration of illness, history of haemoptyses, and the blood sedimentation rates were investigated, but none of them could be correlated with early or late postoperative complications. 
The ability of patients to return to normal life was assessed by their respiratory function and working capacity. The respiratory function has been estimated on clinical grounds alone. Table VII gives the results in 100 cases.

TABLE VII

RESPIRATORY FUNCTION FOLLOWING RESECTION IN 100 CASES

\begin{tabular}{|c|c|c|c|c|c|}
\hline \multicolumn{3}{|c|}{ Time Since Operation } & Good & Moderate & Poor \\
\hline $\begin{array}{l}1-2 \text { years } \\
2-4 \quad ", \\
4-6 \quad ",\end{array}$ & $\begin{array}{l}\cdots \\
\cdots\end{array}$ & $\begin{array}{l}\cdots \\
\cdots \\
\cdots\end{array}$ & $\begin{array}{l}33 \\
28 \\
15\end{array}$ & $\begin{array}{r}4 \\
13 \\
4\end{array}$ & $\begin{array}{l}1 \\
1 \\
1\end{array}$ \\
\hline
\end{tabular}

In 76 patients the respiratory function has been considered to be good, in 21 moderate, and in three poor. A late poor respiratory function has been found in cases where post-operative complications were present.

Table VIII shows the working capacity of 62 patients operated on more than two years ago. In

TABLE VIII

WORKING CAPACITY FOLLOWING RESECTION IN 62 CASES

\begin{tabular}{|c|c|c|c|c|c|}
\hline Follow-up & $\begin{array}{l}\text { No. of } \\
\text { Patients }\end{array}$ & $\begin{array}{l}\text { Full- } \\
\text { time }\end{array}$ & $\begin{array}{l}\text { Part- } \\
\text { time }\end{array}$ & $\begin{array}{c}\text { Not } \\
\text { Working } \\
\text { Fit }\end{array}$ & $\begin{array}{c}\text { Not } \\
\text { Working } \\
\text { Unfit }\end{array}$ \\
\hline $\begin{array}{l}2-4 \text { years } \ldots \\
4-6, ", \ldots\end{array}$ & $\begin{array}{l}42 \\
20\end{array}$ & $\begin{array}{l}28 \\
17\end{array}$ & $\begin{array}{l}3 \\
0\end{array}$ & $\begin{array}{l}4 \\
0\end{array}$ & $\begin{array}{l}7 \\
3\end{array}$ \\
\hline
\end{tabular}

women normal household duties have been accepted as full-time working capacity. There were a few children in this series; they were accepted as capable of full-time work if they returned to normal school life. Table IX compares their occupations

TABLE IX

OCCUPATIONS COMPARED BEFORE AND AFTER ILLNESS

\begin{tabular}{|c|c|c|c|c|}
\hline Follow-up & $\begin{array}{c}\text { Heavier } \\
\text { Work }\end{array}$ & $\begin{array}{c}\text { Same as } \\
\text { Previous } \\
\text { Occupation }\end{array}$ & $\begin{array}{c}\text { Lighter } \\
\text { Work }\end{array}$ & $\begin{array}{c}\text { Not } \\
\text { Working }\end{array}$ \\
\hline $\begin{array}{l}2-4 \text { years } \\
4-6 \quad, "\end{array}$ & $\begin{array}{l}1 \\
1\end{array}$ & $\begin{array}{l}28 \\
13\end{array}$ & 2 & $\begin{array}{r}11 \\
3\end{array}$ \\
\hline
\end{tabular}

before and after the illness. Of the 62 patients, 45 returned to full-time and three to part-time work. Four were not working but fit, and 10 were unfit for work.

\section{Discussion}

This study shows that serious post-operative complications (bronchopleural fistula, spread of disease) occur mainly in the first 12 months after operation. There were no deaths in the late followup period. Resection has not led to clinical evidence of impaired respiratory function in the majority of cases, and the number of patients who were able to return to a normal working life is high.

Primary resection in upper lobe disease was followed by poor results in certain types of case. These were patients with large apical cavities and bilateral fibrocaseous disease, particularly where disease had at some time been present in the lower parts of the lung. For these cases in our experience thoracoplasty still remains the procedure of choice. The reason for the decline in the popularity of this operation in some centres is no doubt due to the respiratory inefficiency which follows an extensive thoracoplasty. With present-day chemotherapy the removal of more than five ribs should rarely be necessary.

In extensive unilateral disease where the volume of the residual lung would not te sufficient to fill the space, thoracoplasty should be done as well as resection. This may be done either as a combined procedure or with the thoracoplasty as a preliminary operation.

Resection has proved to be a satisfactory operation (a) in residual caseous foci, (b) in chronic fibrocaseous disease of segmental or lobar distribution, particularly if some degree of atelectasis is present, and $(c)$ for a failed thoracoplasty.

\section{SUMMARY}

The results from one to six years after operation of 100 resections for pulmonary tuberculosis of the upper lobe have been reviewed.

The radiological appearances, sputum conversion rate, complications, respiratory function, and working capacity have been investigated.

The relative indications for resection and thoracoplasty in upper lobe disease have been discussed.

My thanks are due to Mr. George A. Mason for his helpful criticisms, to my surgical colleagues whose cases have been included in this study, to Dr. M. Walton for his co-operation in the pre-operative investigations, to chest physicians who supplied me with the follow-up material, and to Dr. F. Sorrell for her assistance in the preparation of this paper. 